\title{
Repertoár staré hudby v pražském koncertním životě druhé poloviny 19. století. Vybrané koncertní produkce a jejich reflexe v dobovém tisku
}

\section{Repertoire of Early Music in Prague Concert Life of the Second Half of the Nineteenth Century. Selected Concert Productions and their Reflections in Period Press}

\author{
Magdalena Šmídová Turchichová / magdalenaturchichova@gmail.com \\ Department of Musicology, Faculty of Arts, Masaryk University, Brno, CZ
}

\begin{abstract}
The issue of the performing of early music in the 19th century had been standing rather out of musicological interest until now. Partial studies of the area exist, however, a more comprehensive processing is yet to come. This article outlines a few internal topics regarding matters of the performing, reception, and partly also the interpretative approach to early music in Prague concert life of the second half of the 19th century. The author's focus was directed by the existence of information and reflections in period press about the presence of early music at musical productions. Due to a general lack of sources, period press is a key information resource. Discovered data are compared with printed programs from the fund of printed documentation of Czech Museum of Music. In addition to the above mentioned criteria, the selection was made across spectrum of organizers, that also represent different kinds of activites of concert life.
\end{abstract}

\section{Keywords}

Early Music Revival, 19th Century, Prague Concert Life, Jan Dismas Zelenka, Leopold Alexander Zellner, Josef Förster, Tonkünstler Wittwen-und-Waisen Societät, Prague Conservatoire 
Problematika provozování staré hudby v 19. století prozatím stála spíse na okraji muzikologického zájmu. ${ }^{1}$ Existují k ní sice dílčí studie, na komplexnější zpracování ale ještě čeká. ${ }^{2}$ Následující stat naznačí některá vnitřní témata týkající se otázky provozování, recepce a interpretačního přistupu ke staré hudbě v pražském koncertním životě druhé poloviny 19. století. Pozornost autorky k výzkumu nasměrovala existence dobových reflexí a zpráv o výskytu repertoáru staré hudby na koncertních produkcích. Vzhledem k nedostatku pramenů představuje dobový tisk důležitý informační zdroj. Nalezené údaje jsou porovnávány s tištěnými programy z fondu tiskové dokumentace Českého muzea hudby. Kromě výše uvedených měřítek byl výběr koncertních produkcí veden např́íc spektrem pořadatelských subjektů, které také zároveň reprezentují různé druhy aktivit koncertního života.

\section{Pražský koncertní život v 19. století}

Oproti předešlé epoše, kdy mecenášství bylo v rukou šlechty a kontakt s komponovanou hudbou probíhal přes zámeckou kapelu nebo církevní prostředí, hlavními iniciátory koncertního provozu v 19. století se stali měštané. Jejich sílící vliv znamenal přenos těžiště hudebních produkcí do salónů, jako nového centra kulturního dění, a postupně během první poloviny století do koncertních sálů. Potřebu organizace koncertního života naplňovaly se nově vyvíjející hudební spolky, vzdělávací instituce, ale i samotní umělci.

Dramaturgie koncertů a akademií byla $\mathrm{z}$ dnešního pohledu velice rozmanitá. V programu se mísila čísla nejrůznějšího žánrového zaměření: lidová píseň, orchestrální skladba, árie, deklamace a oblíbené živé obrazy. Zájmy hudebně-dramaturgické často zastiňovaly ty vlastenecké. Hojněji byl uváděn repertoár vycházející spiše z české lidové kultury. Jednalo se o úpravy českých písní, čtverozpěvů či klavírních variací na lidovou píseň. Postupně sílila potřeba provozovat díla dobových českých autorů. Velký důraz byl kladen na jazykovou podstatu, upřednostňována byla čeština.

S notovým materiálem se často zacházelo značně svévolně, byl upravován a aranžován pro potřebná nástrojová uskupení. S obdobným přístupem se setkáváme už na samém počátku snah navracení děl staré hudby na koncertní pódia na konci 18. století. ${ }^{3}$ Velké vokálně-instrumentální skladby se v 19. století bez úprav téměř neobešly.

1 Autorka pro potřeby této studie vymezila pojem „stará hudba“ především časovým ohraničením - tj. tvorbou vzniklou přibližně do poloviny 18. století. Širší vymezení v ŠMÍDOVÁ TURCHICHOVÁ, Magdalena. Znovuoživování staré hudby v českých zemích v 19. století. Muzikologické fórum, 2014, roč. 3, č. 1-2, s. 41-69.

2 K dílčím studiím patř́ např. FREEMANOVÁ, Michaela. Jednota umělcủ hudebních ku podpoře vdov a sirotků, Tonkünstler Wittwen-und-Waisen Societät, 1803-1903 a její role v životě Prahy 19. století. In LEDVINKA, Václav, PEŠEK, Jiří (eds.). Od středověkých bratrstev k moderním spolkům, Documenta Pragensia XVIII, Praha 2000, s. 177-199. BUŽGA, Jaroslav. Bach, Zelenka a česká hudba 19. století. Hudební věda 1982, roč. 19, č. 1, s. 49-60. KOVAČEVIĆ, Tanja. Bach reception in Prague: An 1845 Performance of the Second Kyrie from the B minor Mass. Understanding Bach, 2010, roč. 5, s. 23-48. LUDVOVÁ, Jitka, LÉBL, Vladimír. Pražské orchestrální koncerty v letech 1860-1895. Hudebni věda, 1980, roč. 18, č. 2, s. 99-138.

3 Známé jsou např́klad úpravy Händelových oratorií W. A. Mozarta, I. F. Mosela nebo hraběte Heinricha 
Jedním z neopomenutelných druhů pramenů odrážející zmíněné koncertní konvence je dobový tisk. V něm se postupně ustavovalo kritické referování, především ve specializovaných hudebních časopisech (Caecilie, resp. Cecilie a následně Cyril, Dalibor, Slavoj a Hudební listy). ${ }^{4}$ Ty informovaly čtenáře o hudebních produkcích bud’ předem v oznámení, či následně v obsahově detailnějších recenzích. V souvislosti se zprávou o koncertu byl někdy otištěn také životopis uváděného skladatele. U podrobněǰších recenzí se mohly vyskytovat i reference návštěvnosti, pochvala či pokárání za výběr repertoáru, údaje o účinkujících, případně posouzení jejich interpretace.

$\mathrm{Z}$ hlediska spolehlivosti těchto zdrojů je třeba brát v úvahu několik okolností. Kritika je ze své podstaty subjektivní a recenzenti do ní tedy promítají svá názorová přesvědčení. Zejména po uvolnění politických poměrů v šedesátých letech, kdy se umělecká obec ještě více polarizovala na německou a českou, lze pocitovat v české kritice otevřenější názorovou vyhraněnost směrem $\mathrm{k}$ interpretům hlásících se $\mathrm{k}$ německy mluvící kulturní sfére. České hudební časopisectví se ve druhé polovině 19. století teprve rozvíjelo a odborné články psali mnohdy spíše hudební nadšenci. Se starou hudbou často neměli mnoho zkušeností, a tak k hlubšímu rozboru skladeb, případně specifického interpretačního přístupu, většinou nedocházelo. Autoři se často podepisovali šifrou či značkou, což komplikuje určení autorství článků. ${ }^{5}$ Orientaci v uváděném repertoáru staré hudby ztěžuje také jen částečné nebo nepřesné uvedení názvů skladeb (např. Allemande ze Suity), někdy dokonce i jmen skladatelů. Úroveň kvality svými př́spěvky zvyšoval Otakar Hostinský, který se mimo jiné zabýval problematikou neodbornosti statí. Způsob, jakým směrem by se v historiografii měla ubírat česká hudební věda, naznačil v článku $O$ úloze naši historické literatury hudebni ${ }^{6}$

\section{Pražská konzervatoř}

Jednou z oblastí, skrze níž stará hudba začala pronikat do povědomí posluchačů, byla pedagogická činnost. Díla autorů první poloviny 18. století byla postupně začleňována především do výuky klávesových nástrojů. Tyto tendence můžeme sledovat u Václava Jana Tomáška, ${ }^{7} \mathrm{z}$ institucí na koncertech Prokschova ústavu nebo Varhanické školy pod vedením Carla Ferdinanda Pitsche. ${ }^{8}$

Wilhelma Haugwitze, který vídeňskou tradici uvádění Händelových děl přenesl na zámek v Náměšti nad Oslavou.

4 Časopis Caecilia vycházel v letech 1848-49, od. r. 1874 jako Cecilie, jako Cyril v letech 1879-1948 s přestávkami. Dalibor vycházel v letech 1858-1864 a 1869 red. Emanuel Meliš, 1873-1875 red. L. Procházka a V. J. Novotný, 1879-1913, 1919-1927. Slavoj vycházel 1862-1865, red. A. Pozděna, V. Kubelka a J. Ulm. Hudební listy vycházely 1870-1875. Red. F. Pivoda, J. R. Rozkošný a L. Procházka. Poslední pokus 1889-1890.

5 Slovníky pseudonymů, ale hledané autory výše zmíněných specializovaných časopisů nezahrnují. (VOPRAVIL, Jaroslav. Slovnik pseudonymi̊ v české a slovenské literatuře. Praha 1973. DOLENSKÝ, Antonín. Slovnik pseudonymů a kryptonymů v československé literatuře, Praha 1934.).

6 HOSTINSKÝ, Otakar. O úloze naší historické literatury hudební. Dalibor, 1881, roč. 3, č. 13, s. 97.

7 TOMÁŠEK, Václav Jan: Vlastní životopis (ed. Zdeněk Němec). Praha: Topičova edice, 1941, s. 56-57.

8 Více v ŠMÍDOVÁ TURCHICHOVÁ, Magdalena (2014). 
Velkým přínosem pro pražský hudební život bylo založení Pražské konzervatoře. Už od r. 1815 pořádala veřejné koncerty, které se pro svou kvalitu staly součástí kulturního provozu. Konzervatoř byla další institucí, kde studenti v rámci některých oborů (zprvu zejména u houslí a zpěvu) mohli poznat starou hudbu. Většinou se jednalo o díla J. S. Bacha a G. F. Händela. Žáci pěveckého oddělení se ale seznámili i s díly např. Giacoma Carissimiho, Benedetta Marcella, Alessandra Stradelly, Alessandra Scarlattiho ad.; houslisté zařazovali skladby Arcangela Corelliho, Giuseppa Tartiniho, Antonia Vivaldiho ad.

Studenti se setkali i s velkými vokálně instrumentálními skladbami - $\mathrm{k}$ padesátému výročí založení konzervatoře dne 9. 7. 1858 zazněl Händelův žalm Jubilate Deo [HWV 279] pro sóla, sbor a orchestr. Kromě realizací svých koncertů studenti často vypomáhali na pražských spolkových produkcích, kde byla uváděna velká oratorní díla (ze staré hudby opět především G. F. Händela).

Koncert, který se odehrál dne 21. února 1869, recenzoval v Daliboru Otakar Hostinský. Svůj dojem shrnuje do hodnocení: „Program byl velkolepý a provedeni naveskrz výborné, ano skvělé; tot krátké resumé povšechného dojmu. " Jako první číslo zazněla Bachova Passacaglia c moll [BWV 582] v úpravě J. Essera pro orchestr. Právě zdařilost orchestrace Hostinský v krátké recenzi akcentoval a upozornil na obtížnost tohoto úkolu. „Má-li instrumentováni skladeb původně pro varhany neb piano určených vyhověti $i$ pưvodni esthetické jednotě a harmonické okrouhlenosti celku, $i$ všem zvláštnostem pestrého a všestranného orkestru, jesti k tomu zajisté zapotřbi nejjemnějši znalosti instrumentálni techniky a nejštastnějši kombinace nástrojů rüzných barvitostí, aby se partitura nutným účinkováním větších kompaktnějšich skupin orkestrálnich nestala jednotvárnou a šablonovitou [...]." ${ }^{10}$ Dále pak přiznává, že Bachova Passacaglia na něj zapůsobila nejvíce. Na programu se objevil i představitel italské hudby 17. století - Arcangelo Corelli a jeho „velký koncert pro dvě obligátni housle (O[takar] Ševčik, F[lorian] Zajic) '̌́ello (J[indřich] Korel) s orkestrem“. ${ }^{11}$ Hostinský o skladbě ani provedení podrobnější zprávu nepodal, a tak zatím ani nelze určit, o které concerto grosso se jednalo. Za povšimnutí ale stojí účinkování Otakara Ševčíka. Koncert pražské konzervatoře můžeme řadit mezi jeho první veřejná vystoupení. Ševčík se ve třídě profesora Antonína Bennewitze obeznámil s díly některých barokních skladatelů, které si později našly místo v jeho repertoáru. Na prvním samostatném koncertu v Praze 11. března 1872 uvedl Sonátu Le Tombeau Jean-Marie Leclaira, ${ }^{12}$ 13. a 17. listopadu téhož roku zařadil vedle Paganiniho Koncertu č. 1 i Corelliho houslové variace La Folia.$^{13}$ Obdobný program, ke kterému tentokrát připojil také Bachovu Chaconnu, provedl ve Vídni 15. března $1873 .{ }^{14}$

\footnotetext{
9 HOSTINSKÝ Otakar. Dalibor, 1869, roč. 8, č. 7, s. 55.

10 Ibid.

11 HOSTINSKÝ Otakar. Op. cit. s. 55.

12 Sonata VI. z Troisième Livre de sonates à violon seul avec la basse continue, Paris 1734. Zdroj: Bohemia, roč. 45 , č. $60,10.3 .1872$, s. 942 a Bohemia, roč. 45, č. 64, 15. 3. 1872, s. 1019-1020.

13 Sonáta d moll, Op. 5, č. 12. Zdroj: Dr. Hostinský, Otakar. Die geigeu Koncerte des Herru Otokar Ševčík und L. Breitner, Politik, 1872, roč. 11, č. 321, s. 8.
}

14 Laurencin, hr. Z ciziny a Rakouska. Dalibor, 1873, roč. 1, č. 18, s. 148-149.

Slovním spojením „Bachova Chaconna“ bývá míněna Partita č. 2 [BWV 1004]. 
Recenze k pátému koncertu konzervatoře ze dne 5. 4.1873 se naopak věnuje především interpretaci, což je vzhledem k osobnosti umělce pochopitelné. Julius Stockhausen přijal pozvání ředitelství konzervatoře a vystoupil s blíže neurčenými áriemi od $\mathrm{G}$. $\mathrm{F}$. Händela a G. Bononciniho. Kromě toho zazpíval i Schubertovy písně Greisengesang a Geheimes, jejichž orchestraci provedl Stockhausenův př́itel J. Brahms.

Pozoruhodná je narážka na pěvecké nešvary, které autor shledává u domácích zpěváků a Stockhausenův perfektní přednes jim dává za příklad. „[...] tot jsou vlastnosti, jež, spoji-li se v jeden nerozlučný celek krásy a dokonalosti jako zde u Stockhausena, účinkuji ovšem tím kouzelnĕji na posluchače, č́m více a častě̉i tento musi poslouchati ,božské výkony mnohých pěvců tuzemských. Tremoluje Stockhausen, či uživá tak často ,mazavého' portamenta, překusuje snad fráse hudebni; či vyráži nékteré tony na úkor zrètelné plynné přednášky - či má ve zuyku konečně vydržovati nëkolik těch efektnich toni̊ v poslednich taktech skladby, aby tak vynutil z obecenstva potlesk[?] “15 Tyto interpretační postupy jsou někdy chápány jako „moderní nánosy“, které v 19. století ulpěly na staré hudbě. Možná právě absence tremola a glissanda ve Stockhausenově projevu mohla přispět k příznivému přijetí uvedeného repertoáru. „S pravým klidem umèleckým a dojímavou jednoduchostí zapěl nám, arii‘ Haendlovu, s niž by si byl jiný pěvec zajisté rady ni pomoci nevédèl [...]." ${ }^{\text {"16 }}$

Mimořádnou př́ležitost se seznámit $\mathrm{s}$ tehdy nevšedními skladbami 17. století měli studenti konzervatoře i posluchači při koncertě uspořádaném při př́ležitosti přednášky o dějinách opery Augusta Wilhelma Ambrose dne 11. 2. 1869. ${ }^{17} \mathrm{Na}$ základě Ambrosovy přednášky publikoval v Daliboru Otakar Hostinský stat $O$ vývinu hudebniho dramatu (opery), od poustání jeho okolo $r .1600$ až na nejnovějš́ reformu Richardem Wagnerem..$^{18} \mathrm{~K}$ interpretaci samotné se Hostinský v textu nevyjadřuje. Hudební čísla přednášky používá jako př́ílady specifičností kompozičního stylu dané doby či určitého skladatele. Prvním číslem na programu byla Scena z Euridice Jacopa Periho. Hostinský zdůrazňuje, že Peri spolu s Ottaviem Rinnucinim položili základy současné hudby. Dodává že, „celá naše nynějš́ hudba ,narodila se na jeviští, a tento svioj světský pưvod nezapirá ani tenkráte, když se co moderni , musica sacra" opět do kostela vraci. "19 Fakt, že s hudbou raného baroka nebyli posluchači tolik obeznámeni, potvrzuje Hostinský: „Hudba tato zdá se nám býti sice poněkud cizi, jelikož jeji ,stylo representative' nebo, stylo recitativo" nezná ještě melodii v tom smyslu, jak ji v nové hudbě nalézáme; též naše moderni recitativy jsou něco jiného než zpěvy Periho, při nichž ovšem hlavni věcí jest deklamace co možná správná, avšak dojem těchto prostých a přece tak poëtických tonů jest zajisté mocný a hluboký, ba neodolatelný. “"20

$\mathrm{V}$ dějinách opery se dále posouvá $\mathrm{k}$ dalšímu zásadnímu představiteli rané italské opery - Claudiu Monteverdimu. Na koncertě zazněl „Žalozpěv opuštěné Ariadny z opery téhož

15 Dalibor, 1873, roč. 1, č. 16, s. 132.

16 Ibid.

17 Sóla zpívaly žačky pěveckého oddělení: L. Rubínová, G. Voigtová, Fr. Popelová a M. Spottová a jako host L. Lukes. Doprovázel studentský orchestr. Prof. Vogl doprovázel na klavír, který měl sloužit jako náhrada theorby či loutny. Produkci řídil Josef Krejčí, ředitel konzervatoře.

18 HOSTINSKÝ, Otakar. O vývinu hudebního dramatu (opery). Dalibor, 1869, roč. 8, č. 7, s. 49 a č. 8, s. 59.

19 HOSTINSKÝ, Otakar. O vývinu hudebního dramatu (opery). Dalibor, 1869, roč. 8, č. 8, s. 59.

20 HOSTINSKÝ, Otakar. O vývinu hudebního dramatu (opery). Dalibor, 1869, roč. 8, č. 7, s. 49. 
jména“ a "tanec a sbor z baletni opery Il ballo delle ingrate“, kterou hodnotí jako „velezajímavou“. Pozoruhodná je Hostinského znalost některých historických detailů, z nichž uved'me třeba ten, že provedení Il ballo delle ingrate [...] se i nejvznešenějš́ dámy Mantuanské súčastnily - v baletu. ",21 nebo že Ariadna byla poprvé uvedena k oslavě sňatku Francesca Gonzagy s Markétou Savoyskou v Mantově r. $1608 .{ }^{22}$ U realizovaných částí baletu upozornil na „velmi karakteristicky lokálni ráz podsvètí, jak rhytmem, tak především interessantni harmonisací, nebot' ve sboru tom se objevuje poprvé zmenšený septimový akord, Monteverdem vynalezený.“"23 Poznámka k „vynálezu“ septakordu je poněkud zjednodušující tezí. Nicméně pochopitelná, uvědomíme-li si, že jde o pohled člověka myšlenkově zakotveném $\mathrm{v}$ paradigmatu tonálně funkční harmonie.

Pokračuje dalšími třemi čísly, tentokrát z pera Francesca Galetti Bruni zvaného Cavalli, podle slov Hostinského „nového mistra“, což by mohlo svědčit o tom, že byl pro tehdejší publikum neznámý. V Cavalliho díle zdůrazňuje př́nos pro vývoj árie - začíná krystalizovat její později ustálená forma. Jako první z trojice jeho skladeb zaznělo „duetto Phryny a Praxitela z opery Alcibiade" z r. 1667, následoval duet z opery Elena rapite di Paride z r. 1659 a "proni scéna zpěvohry Artemisia“, ${ }^{24}$ kterou Hostinský poněkud překvapivě zhodnotil jako skladbu ,již docela ve slohu Gluckově psanou“..25

Posledním zastavením v 17. století byla árie z opery Carolo Magno Alessandra Scarlattiho, jehož Hostinský tituluje jako jednoho z nejgeniálněǰších a nejplodnějších skladatelů všech dob, navíc jako nejvýtečnějššho reprezentanta př́edgluckovské italské opery. Jeho význam shledává v ustálení formy arie da capo. Hostinského další hodnocení je zajímavým vhledem do vnímání barokní provozovací praxe. Scarlattiho přínos nalézá ve zdokonalení a obohacení doprovodu zpěvů, jelikož do té doby bylo ještě „velmi primitivni, nebot'v operách Periho použito pro orchestr skoro jen cifrovaného (generálniho) basu, provedeni podrobné prenecháno libosti jednotlivých hráču. "26 Jako velkou devizu Hostinský shledával Scarlattiho úplnou, podrobně propracovanou partituru. Dalším pozitivním vkladem bylo podle něj nahrazení „zastaralých nástrojü“ jako jsou např. theorby a loutny, čímž zjednodušil orchestr. ${ }^{27}$

Závěrečný kus koncertu - sbor furií z Ifigenie Thomamase Traetty - srovnává s Ch. W. Gluckem. Přes vysoké ocenění Traetty považuje za „vítěze“ Glucka. Tento soud zaštituje názorem A. W. Ambrose, ale žádné konkrétní důvody neuvádí.

21 HOSTINSKÝ, op. cit., s. 59.

22 Srovnej s ŠTĚDROŇ, Miloš. Claudio Monteverdi. Génius opery. Praha: Editio Supraphon, 1985.

23 HOSTINSKÝ, op. cit., s. 59.

24 Ibid.

25 Ibid.

26 Ibid.

27 Zdroj této Hostinského domněnky zatím není autorce znám. A. Scarlatti theorby v orchestru použival. Viz NORTH, Nigel. Continuo Playing on the Lute, Archlute and Theorbo. Bloomington: Indiana University Press, 1987, s. 21. 


\section{Historické koncerty}

Tzv. historické koncerty se pořádaly ve Vídni již na sklonku 18. století, a to prostřednictvím barona Gottfrieda Bernharda Swietena (1733-1803) a Rafaela Georga Kiesewettera (1773-1850). Jejich počiny v tomto ohledu jsou vcelku známé, ${ }^{28}$ stejně jako aktivity hraběte Heinricha Wilhelma Haugwitze (1770-1842), který tento fenomén z Vídně přenesl na své sídlo v Náměšti nad Oslavou. ${ }^{29}$ Tradici pořádání historických koncertů převzaly v 19. století většinou zájmové spolky (Hlahol, Žofínská akademie, Ceciliánský spolek, Jednota hudebních umělců), podobné aktivity ale začínali vyvíjet i významní interpreti, kteří přirozeně přitáhli pozornost publika i tisku.

Dne 12. 3. 1864 v Konviktském sále uvedl historický koncert s přednáškou Leopold Alexander Zellner, redaktor vídeňského hudebního časopisu Blätter für Musik, profesor harmonie na vídeňské konzervatoři a hráč na harmonium, pro něž byla velká část skladeb z repertoáru upravena. ${ }^{30}$ Zellner byl ve Vídni známý aktivitami, které měly posluchače vzdělávat a „brousit“ jejich hudební vkus. Proto od. r. 1859 pořádal historické koncerty, kde publikum seznamoval s díly, které v běžném koncertním repertoáru neměli šanci slyšet.

Právě nad výběrem repertoáru na Zellnerově pražském koncertu se recenzent časopisu Slavoj pozastavil: „[...] mlčením pomineme, že sestaveni programu bylo někdy nahodilé a že jsme postrádali skladby některých výtečných mistrů, které slabšim pracím ustoupiti musely. "31 Ovšem následně z textu vyplývá, že hlavní problém tkvěl v tom, že Zellner zcela opominul skladby českých autorů, což mohlo zapříčinit roztrpčení kritiky.

Na programu zazněla vánoční píseň Noel ze 14. století pro sólový soprán a mužský sbor s doprovodem harmonia, a dále Písen od Thibauta. ${ }^{32}$ Milostnou piseň od Osvalda Wolkensteina $^{33} \mathrm{v}$ podání tenoristy Jana Ludevíta Lukese za doprovodu moderní harfy shledal kritik jako umělecky velmi slabou (na rozdíl „od skvělého prednesu L. Lukese“). Následovala čtyřhlasá Píseň Mariánská Michaela Praetoria, Passacaglia Girolama Frescobaldiho, Partita (v tištěném programu jsou uvedeny části: ouvertura a fugato, allemande, courrante, arie, menuetto a finale) ${ }^{34}$ Gottlieba Muffata (1690-1770), Sonáta pro dvoje housle, violu a violoncello (largo, allegro, menuet, aria a gigue) Francesca Veraciniho

28 Více KIER, Herfrid. Raphael Georg Kiesewetter (1773-1850). Wegbereiter des musikalischen Historismus. Studien zur Musikgeschichte des 19. Jahrhunderts. Bd. 13, Regensburg 1968, s. 23, 48-49, 223-224.

29 Hudebním provozem v Náměšti nad Oslavou se poprvé zabýval Karel Vetterl ve studii: VETTERL, Karel. Bohumír Rieger a jeho doba. Časopis Matice moravské, 1929, roč. 53, s. 45-86, 435-500. Téma dále zpracovávali Jan Racek, Rudolf Pečman, Jiří Sehnal, Miloš Štědroň, Markéta Jůzová a další.

30 Na provedení se dále podíleli: Eleonora Ehrenbergerová (zpěv), Jan Ludevít Lukes (zpěv), L. A. Zellner (harmonium), A. Kolarová (klavír), Václav Alois Staněk (harfa), Mořic Mildner (housle), Eduard Wittich (housle), Jan Weber (viola), Mořic Wagner (violoncello) a nejmenovaný sbor.

31 Slavoj, 1864, sv. 4, č. 7, s. 115.

32 Thibaut, král Navarský a trubadúr (cca 1201-1253).

33 Básník, skladatel a diplomat (1376/77-1445).

34 České muzuem hudby (С̌MH), fond tiskové dokumentace, sig. TP 85. 
(1698-1764), Aria di camera pro soprán (s doprovodem klavíru) Johanna Adolfa Hasseho (1699-1783), Suita pro klavír (courant, gavota a 3 doubles, sarabandu a finale) Jeana Philippa Rameaua (1683-1764), Sarabanda a gavotta J. S. Bacha, a Adagio z Kvintetu g moll W. A. Mozarta. Hodnocení kritiky se zaměřilo převážně na Zellnerovu interpretaci. Oceněn byl přednes, především „pak u skladeb kontrapunktických, kde mistrně vyznačil jednotlivé částky, $z$ nichž se skládaji. “35

Aktivity podobné Zellnerovým realizoval např. také Josef Förster. Z recenze v Daliborovi i pozdějších zpráv se zdá, že z jeho historických koncertů se stala tradice spojená s Velikonočním pondělím. Stejně jako Zellnerův koncert i tento proběhl v Konviktském sálu a Förster také hrál na harmonium. ${ }^{36}$ Možná právě kvůli zvolenému nástroji není náhodou, že dvě čísla programu se shodují s programem L. A. Zellnera (Píseň od Thibauta a Píseň milostná O. Wolkensteina). Starou hudbu reprezentovaly také písně Když krásu božích stvořeni ${ }^{37}$ a Tak tedy lásko jedina $a^{38}$ ve Försterově úpravě pro sbor a harmonium, dále Suita e moll Johanna Ernsta Bacha ${ }^{39}$ a Dignare o Domine z Utrechtského Te Deum [HWV 278] G. F. Händela. ${ }^{40}$

O poznání pestřejší program provedl Josef Förster na Velikonoční pondělí 6. 4. 1885. Koncert se odehrál v Rudolfinu a za nástroj byly zvoleny varhany, které jistě poskytovaly možnost širšího výběru repertoáru. Program sestavený z děl ze čtyř století byl hodnocen velice pozitivně, protože „,elek podával velmi zajimavý obraz o vývoji a postupu novověké hudby. " ${ }^{41}$ Spoluúčinkovali altistka [?] Schmidt-Alizarová ${ }^{42}$ a houslista Antonín Bennewitz. V podání Josefa Förstera zazněla Ricercata G. P. da Palestriny, Passacaglia G. Frescobaldiho, Prealudium a fuga a moll J. S. Bacha a „effektni variace zesnulého $i$ u nás známého vratislavského varhanika Adolfa Hesseho [sic!]“. ${ }^{43}$ Försterova „technická jeho dokonalost na manuale i pedale, duchaplný prédnes a štastné kombinováni jednotlivých rejstř̌̌k ¿“44 na posluchače velice zapůsobila. Pěvkyně Schmidt-Alizarová přednesla árii $A h$, rendimi quel core z opery Mitrane Francesca Rossiho za klavírního doprovodu Augustina Vyskočila, sbormistra Národního divadla. A. Bennewitz hrál na housle s doprovodem varhan Largo z nejmenované skladby G. F. Händela. Přesto, že Bennewitzova hra byla oceněna jako přesná a př́ijemná, připomínku si vysloužila opět volba skladby německé provenience.

35 Ibid.

36 Spoluúčinkovali Vojtěch Šebesta a Marta Procházková.

37 Mohlo by se jednat o stejnojmennou píseň z ŠTEYER, Václav Matěj. Kancionál český. Praha 1683, s. 850.

38 V recenzi je píseň připsaná Karlu Holanovi Rovenskému, zřejmě se ale jedná o Michnovu píseň ze sbírky Česká mariánské muzika.

39 V recenzi jsou uvedená životní data 1683-1730. Mohlo by se jednat o Johanna Ernsta Bacha z Arnstadtu (1683-1739). Zdroj: WOLFF, Christoph. Bach, Johann Ernst. In Grove Music Online [online]. Oxford Music Online [cit. 31. 8. 2017]. Dostupné z: http://www.oxfordmusiconline.com/subscriber/article/grove/music/40023pg1?q=Johann+Ernst+Bach+\%281683\%E2\%80\%931730\%29\&search=quick\&pos=1\&_start=1\#firsthit.

40 Dalibor. 1873, roč. 1. č. 14, s. 114.

41 Dalibor. 1885 , roč. 7 č. 14 a 15 , s. 141.

42 Ačkoli se jednalo o poměrně známou umělkyni, v dostupných zdrojích není uvedeno její křestní jméno.

43 Op. cit, s. 142.

44 Ibid. 
Ovšem tentokrát byla vyřčena s konkrétním požadavkem. Roku 1867 byla poprvé vydaná tzv. Davidova sbírka - Die hohe Schule des Violinspieles. ${ }^{45}$ Obsahovala 20 skladeb, většinou sonát, v úpravě pro housle a klavír a těšila se velké oblibě. Vedle autorů, povětšinou ze 17. a 18. století, jako byli např. Corelli, Porpora, Vivaldi, Leclair, Nardini, Veracini, Bach, Händel, Tartini, Vitali, Locatelli, Pisendel, se vyskytoval i H. I. F. Biber. Právě jeho soná$\mathrm{tu}^{46} \mathrm{z}$ této sbírky představil v prosinci 1882 houslista Ferdinand Lachner na historickém koncertě Umělecké besedy. Podobnou invenci při výběru repertoáru zřejmě čekala kritika i od Bennewitze.

\section{Uvádění díla J. D. Zelenky}

Je možné, že začleňování děl G. F. Händela a J. S. Bacha do koncertního provozu vzbudilo zájem o hledání nemenšího velikána české provenience. Sílící tendence v tomto směru můžeme pozorovat v šedesátých letech 19. století.

Už v roce 1857 publikoval Emanuel Meliš v Lumíru životopisný článek o Janu Dismasu Zelenkovi, na něj navázal v Daliboru Vítězslav Guth roku $1859,{ }^{47}$ a týž článek s drobnými úpravami publikoval roku 1863 ve Slavoji. Guth v něm upozorňuje: „V archivu královského katolického chrámu Drážd'anského, nalezá ze mnoho skladeb Zelenkových, nám co do podstaty své z větši části neznámých. Jestit’ tam uloženo 21 mši, 3 rekviem, 3 oratorie, 108 žalmü, litanii a hymen; mezi mšemi jest nejznamitějši do G a mezi ostatnimi skladba ,Alla capella: Prohlédajice $k$ tomu, že byl Zelenka žákem Fuxovým, pridáváme se $k$ náhledu, že skladby Dismasovy se mohou pokládati za vzor sazby čisté, za vzor ostrovtipu pronikajicího a hlubokého vědomi veškerých poměrů hudebnich.“ Na závěr stati dodává: „Dovolime si toliko tuto otázku: ,Kdo z nás zná skladby Zelenkozy?‘ Pohřichu pokrčime ramenama, ukazujice k Drážd’anům, kde autografy vlastence našeho ve skř́ni, jež jmenem skladatelovým jest nadepsána, pochovány a pohřbeny jsou, aby snad božího světla nespatřily. "48 $\mathrm{O}$ dva měsíce později se ve Slavoji objevuje zpráva, že 9. března Dresdner Tonkünstler-Verein uvedl Zelenkovu Svitu pro 2 housle, violu, 2 hoboje, 1 fagot $i$ cello a bassu zkomponovanou v roce $1723 .{ }^{49}$ Stejné dílo, jednalo se o Ouverturu F dur [ZWV 188], bylo pak 30. července roku 1863 představeno v pražském Novoměstském divadle.

Ohledně této události se v odborné literatuře vyskytují spekulace nad tím, že Zelenkovu skladbu dovezl a provedl Bedřich Smetana. Jak uvádí Rudolf Pečman, Smetana měl se starou hudbou zkušenosti. Dirigoval totiž už v letech 1856-1861 v Götteborgu Händelova oratoria Jephta a Messiah, ${ }^{50}$ navíc Händelovy a Bachovy skladby se objevovaly na repertoáru

45 Vydána u nakladatelství u Breitkopf \& Härtel. Editorem byl Ferdinand David (1810-1873).

46 Sonáta VI c moll, C 143.

47 GUTH, Vítězslav. Jan Dismas Zelenka. Dalibor, 1859, roč. 2, č. 21, s. 161.

48 GUTH, Vítězslav. Jan Dismas Zelenka. Slavoj, 1863, sv. 2, č. 2, s. 29.

49 ZWV 188: Overture à 7 Concertanti in F, 1723, [2Ob.; Bn.; 2Vn.; Va.; B.c.].

50 PEČMAN, Rudolf. Händel-Konferenz 1997. Georg Friedrich Händels Oratorien und ihre Wirkung auf das 
jeho klavírních recitálů..$^{51}$ Josef Srb Debrnov píse, že právě roku 1863 Smetana v drážd’anském archivu byl a nějaký opis přivezl. ${ }^{52}$ Nicméně, jak uvádí Jana Vojtěšková, ve Smetanově deníku sice je poznámka o cestě do Dráždan, i to, že mu byl nápomocen krajan František Suchánek, ovšem žádné další záznamy o této záležitosti (a především to, že byl vezl do Prahy nějaké Zelenkovy opisy) v deníku nejsou.$^{53}$ Zdá se také velice nepravděpodobné, že pokud by Smetana zmíněnou Ouverturu přivezl a dokonce řídil její provedení, tisk by takovou událost nechal bez povšimnutí. O provedení Zelenkovy Ouvertury F dur v Novoměstském divadle hudební časopisy podrobnější reflexi neposkytly, snad jen ve Slavoji je z krátkého oznámení zřejmé, že dva hoboje byly nahrazeny lesními rohy. ${ }^{54}$ Hodnocení se chopil denní tisk, a to noviny Politik. V recenzi se dozvídáme, že produkci dirigoval kapelník Eduard Tauwitz. Autor ale hodnotil také Zelenkovu skladatelskou osobnost:

„Die Suite für Orchestr von Joh. Dismas Zelenka überzeugte uns, dass die Zeitgenossen den Componisten dadurch das sie ihn an die Seite Händel's und Bach's setzten keineswegs überschätzt haben; es waltet darin ein Grosser Geist, der nicht allein durch kontrapunktische Gewandtheit und Kunst, sondern auch durch Originalität der Erfindung in Melodie und Rhytmus wie auch in einer merkwürdigen Beherschung und Anwendung der instrumentalen Mittel sich manifestiert. " ${ }^{55}$

Organizátoři uvedení Zelenkovy Ouvertury v Novoměstském divadle se zasloužili i o další provedení jeho díla. Dvouleté snahy o obnovení hudebního provozu v odsvěceném chrámu sv. Mikuláše na Staroměstském náměstí vyvrcholily v květnu 1865 velkolepým koncertem, na kterém se měli podílet v nadsázce snad všichni pražští hudebníci. Produkci předcházela několikrát otištěná výzva pražského purkmistra ředitelům kůrů, aby laskavě zapůjčili k této akci své zpěváky. Organizační komité přizvalo k provedení „,nejčelnějši výkonné hudebniky“, ${ }^{56}$ což je vzhledem k vybranému repertoáru pochopitelné.

„Že program sestaven jest pouze z děl slavnosti důstojných, netřeba zvläště podotýkati. Krom toho hledèli jsme $k$ tomu, aby pokud možné, srovnával se zároveň s rozličnými směry, a protož nacházeji se v něm díla staršîho i novějšĭho času - dle tř́ škol: vlaské, české a německé - jakož z programu samého patrno jest. " ${ }^{57}$ Na programu zazněla blíže nespecifikovaná díla: osmihlasé Gloria Giovanni Lorenza Marianiho, Et Incarnatus Luigi Cherubiniho, Lamentatio Jana Dismase Zelenky a Kyrie z Missa solennis d-moll Josefa Krejčího. Dále Introductio z Matou-

kompositorische Schaffen im 19. Jahrhundert. Halle a. d. Saale, 9.-10. 6. 1997. Hudebni věda, 1997, roč. 34, č. 4 , s. 437 .

51 Dne 5. 1. 1862, Koncert B. Smetany, na programu blíže neurčený Allemande a Gigue G. F. Händela. Zdroj: Dalibor, 1862, roč. 5, č. 1. s. 8. Dále dne 18. (19.?) 1. 1862 Koncert B. Smetany, na programu blíže neurčené Gavotte a Gigue J. S. Bacha. Zdroj: Dalibor, 1862, roč. 5, č. 4. s. 31.

52 SRB DEBRNOV, Josef. Z deniku Bedřicha Smetany. Praha: M. Urbánek, 1902, s. 63.

53 VOJTĚŠKOVÁ, Jana. Dílo Jana Dismase Zelenky v 18. a 19. stoletív Praze. In KROUPA, Jiří (ed.). Clavibus unitis, Praha: Nadace pro dějiny kultury ve střední Evropě, 2015, roč. 4, s. 88-89.

54 Slavoj, 1863, sv. 3, č. 1, s. 13-14.

55 Politik, roč. 2, č. 179, 1. 7. 1863, večerní vydání, s. 1.

56 Slavoj, 1865 , sv. 6, č. 7 , s. 113.

57 Slavoj, 1865, sv. 6, č. 8, s. 130. 
šových pašiji J. S. Bacha [BWV 244] a Händelovo Utrechtské Te Deum [HWV 278].58 Řízení se ujal Josef Krejčí.

Zprávu o provedení podal v časopisu Slavoj Mates Šídlo. Píše, že navzdory velké propagaci a doporučení byl koncert navštíven méně než by zasluhoval, a to zejména hudebními autoritami. Celkově pak Šídlo hodnotí provedení jako uspokojivé, zvlášt velké obsazení sboru a orchestru tradičně velmi ocenil. K interpretaci Zelenkovy Lamentace a úvodního sboru Matoušových pašijí měl ale určité výhrady. „Slyšel jsem navzdor tomu, že pěvec part svioij výborně zpival, na mistě pisně žalostivé, brilantni solo církevni přednášeti. Tempo tohoto č́sla mèlo býti mnohem zdlouhavější. Ano is tempem skladby Bachovy nemohu býti srozumèn. Účinek tohoto čisla byl - na mistě očekávané širre - takřka banálni. " ${ }^{59}$ Právě nevyhovující tempo bylo často předmětem kritiky při hodnocení interpretace staré hudby.

Ačkoli snahy přiblížení díla J. D. Zelenky byly v šedesátých letech relativně intenzivní, masivní zájem o jeho hudbu a osobnost nevyvolaly.

\section{Jednota hudebních umělců}

Činnost spolků hrála v koncertním životě 19. století zásadní roli. Své nenahraditelné místo v něm získala Jednota hudebních umělců k podporování vdov a sirotků (Tonkünstler Wittwen-und-Waisen Societät). Podobné umělecké spolky vznikaly v Evropě již v 18. století - v Londýně, Berlíně, Petrohradě ad. Vzorem pro založení pražského spolku se stala vídeňská Tonkünstler-Societät. R. 1771 ji ve Vídni založil skladatel českého původu Florian Leopold Gassmann. ${ }^{60}$ Tonkünstler Societät byla nejstarší a na dlouhou dobu také jedinou hudební institucí, která se věnovala provozování velkých oratorních děl. Elizabeth Hilscher ve své studii o vídeňské Tonkünstler Societät upozorňuje na zajímavý moment, kdy se provozování oratorií př̀sunulo ze semi-liturgických prostor a stalo se součástí koncertních akademií ${ }^{11} \mathrm{~S}$ liturgickým prostředím je spojovalo načasování produkcí, tj. ve Svatém týdnu a před Vánočními svátky. Model tohoto hudebního provozu převzala pražská Jednota téměř bezvýhradně. Pro volbu velkých vokálně-instrumentálních děl byla příznivou okolností silící obliba sborových projektů za účasti orchestru. Jednota hudebních umělců od svého založení pořádala dvakrát ročně akademie, na nichž uváděla kantáty a oratoria a stala tak nejvýznamnějším provozovatelem oratorií v Praze. ${ }^{62}$

58 Tištěný program uvádí totožné autory i díla. Zdroj: ČMH, sig. TP 104.

59 ŠÍDLO, Mates. Provozování skladeb duchovních. Slavoj, 1865, roč. 6, č. 10, s. 179.

60 HILL, George R., KOSMAN, Joshua. Gassmann, Florian Leopold. In Grove Music Online [online]. Oxford Music Online [cit. 22. 9. 2017]. Dostupné z: http://www.oxfordmusiconline.com/subscriber/article/grove/ music/10717.

61 Více v FRITZ-HILSCHER, Elizabeth. Die großen Oratorien-Produktionen der Tonkünstler-Societät in Wien Kontrapunkt oder Nachfolger der höfischen Oratorienpflege des Barock? Musicologica Brunensia, 2014, roč. 49 , č. 1, s. 211-234.

62 Michaela Freemanová uvádí, že základem provozovacích materiálů bylo „neusten Oratorien und Cantaten“ pořízené ve Vídni, které Jednotě daroval kníže Josef Lobkovic. Více v: FREEMANOVÁ, Michaela. Jednota umělců hudebních ku podpoře vdov a sirotků. Tonkünstler Wittwen-und-Waisen Societät (1803-1903) a její role 
K př́ležitosti stoletého výročí úmrtí G. F. Händela bylo dne 18. dubna roku 1859 provedeno jeho oratorium Samson [HWV 57]. Zhodnocení projektu přináší recenze v Daliboru: „Oratorium ,Samson' vyniká hlavně svými mohutnými, významnými, unášejícími sbory, kteréž bujarou silou a svěžestí se vyznačuji. Méně zajímavé jsou arie, ježto co do pưvabnosti ariim ostatnich Händlových oratorii ustoupiti musî." "63 Zmíněnou mohutnost sborů, které $\mathrm{v}$ té době byly velice oblíbené, podpořily svou účastí další spolky a hudební instituce. Pod taktovkou Františka Škroupa ${ }^{64}$ účinkoval Ceciliánský spolek, Žofínská akademie, studenti Pražské konzervatoře a členové orchestru Stavovského divadla. Obsazení tedy bylo zřejmě ohromné, což byla okolnost, která velmi přitahovala pozornost tisku.

Spolupráce spolků a hudebních institucí nebyla v té době neobvyklá. V Daliboru se můžeme dočíst o dalším koncertě Jednoty umělců z 26. března 1861 v Žofínském sále.

„K provedeni nepřišlo dle obyčeje oratorium, nýbrž dvě menši skladby [Stabat mater G. B. Pergolesiho a Davidde penitente W. A. Mozarta]. ,Stabat mater' od Pergolesiho zasluhuje veřejného provedeni a téż $i$ chvály. Pohnutlivá skladba tato dává nejlepši svědectvi o jeho sentimentálním charakteru. "65 Podle oznámení, recenzí i samotného tištěného programu koncertu $^{66}$ se se jednalo o první uvedení Pergolesiho Stabat Mater v Praze, možná právě proto si koncert získal velkou publicitu. ${ }^{67}$ Kantátu v aranži Alexise Lvova realizovaly výše zmíněné instituce, rozšsiřené o množství amatérských muzikantů a pod vedením Wilhelma Jahna, kapelníka Stavovského divadla. Sólové party byly svěřeny Emilii Mikové a Josefině Schmidt-Procházkové. Autor recenze v časopisu Dalibor čtenářům krátce přiblížil osobnost skladatele G. B. Pergolesiho, bohužel k reflexi interpretace kantáty nedošlo, nebot jeho pozornost strhly obtíže sboru i sólistů při provedení druhé skladby Davidde penitente [K 469]. Právě tuto Mozartovu kantátu provedla poprvé r. 1785 v Burgtheater vídeňská Tonkünstler Societät. ${ }^{68}$

Zásluhy Jednoty na šiřrení povědomí o starohudebním repertoáru Emanuel Meliš hodnotí: "Jednota hudebnich umeelců prispěla nemálo $k$ probuzeni lásky obecenstva $k$ tomuto druhu hudby výtečným provedením oratorii Haendlových, která teprv v tomto stoleti v Praze se provozovala. Jednota seznámila obecenstvo Pražské téměr s každým klassickým neb alespoň vynikajicím dílem v oboru tomto a snaži se všemožně i novějši skladby oratorni mu předvésti. “69

v životě Prahy 19. století. In Od středověkých bratrstev k moderním spolkưm, Documenta Pragensia, roč. 18. Praha 2000, s. 177-199.

63 Dalibor, 1858, roč. I, č. 5, s. 18.

64 Od 1837-1857 prvním kapelníkem ve Stavovském divadle, později si otevřel pěveckou školu.

65 Dalibor, 1861, roč. 4 , č. 10. s. 82.

66 С̆MH, sig. TP 41.

67 Dalibor, 1861, roč. 4, č. 9. s. 74. Prager Morgenpost, roč. 8, 22. 3. 1861 a 26. 3. 1861. Prager Zeitung, č. 75, 28. 3. 1861.

68 Za upozornění na tuto skutečnost děkuji Janě Perutkové.

EISEN, Cliff, SADIE, Stanley. Wolfgang Amadeus Mozart. In Grove Music Online [online]. Oxford Music Online [cit. 31. 8. 2017]. Dostupné z: http://www.oxfordmusiconline.com/subscriber/article/grove/music $/ 40258$ pg3? $=$ Davidde + penitente\&search=quick\&pos=3\&_start=1\#firsthit.

69 MELIŠ, Emanuel. O působení jednoty hudebních umělců Pražských k podporování vdov a sirotků. Dalibor, 1863 , roč. 6 , č. 11 , s. 81 . 
Za pozornost stojí také provedení Vánočního oratoria [BWV 248] J. S. Bacha uspořádané Jednotou hudebních umělců dne 23. prosince 1878. V tisku se k této události nachází nezvykle rozsáhlé hodnocení, dokonce si vysloužila celý článek v Daliboru. Jednota seznámila publikum s oratorní tvorbou J. S. Bacha o Velikonocích r. 1877, kdy provedla části z Matoušových pašiji ${ }^{70}$ Vánočni oratorium slyšela Praha poprvé, a to dokonce v českém jazyce. ${ }^{71}$ Text k oratoriu přeložil Václav Juda Novotný, mimo jiné redaktor Dalibora, party pro orchestr upravil v moderním duchu a pro moderní obsazení Zdeněk Fibich, sbory nastudoval [?] Follberger, ${ }^{72}$ dirigoval Adolf Čech.

$\mathrm{Z}$ reflexe Václava Judy Novotného si můžeme vytvořit určitou představu, jak asi provedení mohlo vypadat. Tak velká událost byla s napětím očekávána. V recenzi byl oceněn předseda Jednoty Jan Ludevít Lukes za uvedení velkých vokálně instrumentálních děl J. S. Bacha. Ovšem vcelku se očekávání zřejmě úplně nenaplnila. Novotný upozornil na to, že jednotlivé části šestidílného oratoria byly určeny na různé svátky vánoční a provozovat dílo na jednom koncertě považoval za neštastné. Vynikla tak totiž určitá „jednotvárnost tekstu, jež $i$ na hudbu přirozeně přšla. “73 Takové dramaturgické uspořádání pokládal Novotný při nejmenším za posluchačsky náročné. Zdlouhavosti produkce zřejmě nepomohlo ani to, že „množstvi vedlejšich čisel se při provedeni vynechalo. "74 Překladem libreta do českého jazyka vznikala také určitá úskalí. V nejnutnějších případech bylo nutné změnit melodické úseky v recitativech, aby se vyhovělo novému textu.

$\mathrm{V}$ hodnocení interpretace shledával recenzent především u sólistů ${ }^{75}$ absenci zkušenosti s podobným repertoárem. „Pokud se týče nastudováni a provedeni Bachových oratorii dlužno celkem uznati, že jak dirigenti, tak i ostatni výkonni umělci nesnadné té úlohy se chápali s chuti a patrnou pili. Sbory silně obsazené statečně si počinaly nejen v podáni překrásných choráli̊, nýbrž $i$ v ohnivém, rytmicky správném přednesu figurovaných a fugírovaných vět sborových; solisté snažili se - každý dle svého nadáni - dostáti úplnou měrou obtižné a nezvyklé té úloze, $i$ jest dle všeho jisto, že všichni častějšim opakováním skladeb těch hlouběji dovedou vniknouti $v$ ducha složitých těch prací, což se dosud jednotlivým pouze výjimkám podařilo. "76

Ještě další interpretační problém shledal Novotný v provedení Vánočního oratoria. Ten byl natolik zásadní, že ho přiměl k sepsání samostatné stati $O$ přednášce recitativů v J. S. Bachových. Upozorňuje v ní na to, že zpěváci nerespektovali tzv. „pravidlo zuýšeného tónu“, tj. uplatnění kvartové či sekundové opory na předposlední notě v kadenci recitativu. Příčinou popisovaného nedostatku bylo doslovné čtení notového zápisu, kdy předposlední

70 Dne 21. 2. 1878.

71 Což bylo u Jednotou prováděných oratorií tehdy běžnou praxí.

72 Mohlo by se jednat o Bedřicha Follbergera. ČSHS uvádí pouze heslo Jan Follberger (1811-1871). Varhaník v chrámu sv. Víta, u P. Marie v Loretě a na Strahově, měl syna Bedřicha Follbergera, který po něm na poslední dvě jmenovaná místa nastoupil. ŠTĚDROŇ, Bohumír. Follberger, Jan. In ČERNUŠÁK, Gracian, ŠTĚDROŇ, Bohumír, NOVÁČEK, Zdenko. ČSHS I. Praha: Státní hudební vydavatelství 1963, s. 338-339.

73 Dalibor, 1879, roč. 1, č. 2, s. 16.

74 Ibid.

75 Betty Fibichová, Eleonora Ehrenbergerová, Antonín Vávra a Karel Čech.

76 NOVOTNÝ, Václav Juda. O přednášce recitativů v J. S. Bachových oratoriích. Dalibor, 1879, roč. 1, č. 2, s. 10 . 
i poslední nota jsou zapsané ve shodné výšce. Nutno poznamenat, že se tento jev vyskytoval při interpretaci staré hudby u nepoučených hudebníků i během celého 20. století (ve vzácných př́padech ho lze zaznamenat dodnes). Přes tyto překážky autor přiznal zpěvákům snahu o jistý stupeň výrazu.

„[...] Nenapadne zajisté žádnému rozumnému hudebniku, aby tento deklamačni zákon popirati chtěl u skladatel ̊ jako jest např. Keiser, Teleman, Haendl, Graun, Gluck, Haydn a Mozart; což pak tedy probůh zavinil poctivý mistr Bach, že se s ním zacházi, jako by byl neznal elementárnich pravidel v psani a čteni recitativu, kdežto přec za jeho doby pravidla ta musel znáti každý vokalista!? Proč se tedy znetvořuji jeho mistrovská díla spiosobem, který bychom ani poslednímu vesnickému kantoru neodpustili? Tu slyšeti musime pošetilou výmluvu: ,Bach to tak napsal, a na tom se nesmi ničeho měniti!’ - Ano; ov̌̌em že to tak napsal; ale vy, moudř pánové, - vy to neumíte čisti!" "i7

Navzdory uvedeným nesnázím se zdá, že provedení Vánočního oratoria mělo úspěch. Jednota hudebních umělců ho do konce svého působení zopakovala ještě dvakrát (1883, 1888).

\section{Závěrem}

V dnešní době je pro nás dobový tisk často jediným pramenem k událostem v pražském koncertním životě. Neslouží pouze jako podklad pro vytvoření soupisu uváděného repertoáru, do jisté míry ukazuje také vztah odborné i umělecké veřejnosti ke staré hudbě a poskytuje neocenitelný vhled do společenského dění v 19. století. Zdánlivě banální informace pomáhají doplnit celkovou podobu koncertního života, resp. pohled na provozování staré hudby. Recenze poodhalují dobový vkus i důvody, proč se určité formy držely v koncertním repertoáru. Dokládají, že i tehdy existovaly na interpretaci různé názory a její nevhodné uchopení mohlo mít za následek nepochopení některých děl. V neposlední řadě je zajímavé sledovat vývoj české hudební kritiky od volně písíícich hudebních spisovatelů až po odbornější a vyzrálejší stati Otakara Hostinského.

Uvedené koncertní události zřejmě nevydaly zásadní impuls pro mohutný návrat staré hudby do běžného koncertního repertoáru devatenáctého století. Výše představené aktivity ale můžeme chápat jako postupné pokládání základů pro pozdější vědomě budovaný zájem o starou hudbu.

\section{Bibliography}

Dalibor, 1858, roč. 1 , č. 5 , s. 18 .

Dalibor, 1862, roč. 5 , č. 1 , s. 8 .

77 Ibid. 
Dalibor, 1862 , roč. 5 , č. 4 , s. 31 .

Dalibor, 1873, roč. 1, č. 16, s. 132.

Dalibor. 1873, roč. 1, č. 14, s. 114 .

Dalibor, 1879, roč. 1, č. 2, s. 16.

Dalibor. 1885 , roč. 7 , č. 14 a 15 , s. 141.

EISEN, Cliff, SADIE, Stanley. Mozart, Wolfgang Amadeus. In Grove Music Online [online]. Oxford Music Online [cit. 31. 8. 2017]. Dostupné z: http://www.oxfordmusiconline.com/subscriber/ article/grove/music/40258pg3?q=Davidde+penitente\&search=quick\&pos=3\&_start=1\#firsthit.

FREEMANOVÁ, Michaela. Jednota umělců hudebních ku podpoře vdov a sirotků. Tonkünstler Wittwen-und-Waisen Societät (1803-1903) a její role v životě Prahy 19. století. In Od středověkých bratrstev k modernim spolkům, Documenta Pragensia, roč. 18. Praha 2000, s. 177-199.

FRITZ-HILSCHER, Elizabeth. Die großen Oratorien-Produktionen der Tonkünstler-Societät in Wien Kontrapunkt oder Nachfolger der höfischen Oratorienpflege des Barock? Musicologica Brunensia, 2014, roč. 49, č. 1, s. 211-234.

GUTH, Vítězslav. Jan Dismas Zelenka. Dalibor, 1859, roč. 2, č. 21, s. 161.

GUTH, Vítězslav. Jan Dismas Zelenka. Slavoj, 1863, sv. 2, č. 2, s. 29.

HOSTINSKÝ Otakar. Dalibor, 1869, roč. 8, č. 7, s. 55.

HOSTINSKÝ, Otakar. O vývinu hudebního dramatu (opery). Dalibor, 1869, roč. 8, č. 7, s. 49 a č. 8 , s. 59.

HOSTINSKÝ, Otakar. O úloze naší historické literatury hudební. Dalibor, 1881, roč. 3, č. 13, s. 97. HILL, George R., KOSMAN, Joshua. Gassmann, Florian Leopold. In Grove Music Online [online]. Oxford Music Online [cit. 22. 9. 2017]. Dostupné z: http://www.oxfordmusiconline.com/subscriber/article/grove/music/10717.

KIER, Herfrid. Raphael Georg Kiesewetter (1773-1850). Wegbereiter des musikalischen Historismus. Studien zur Musikgeschichte des 19. Jahrhunderts. Bd. 13, Regensburg 1968, s. 23, 48-49, 223-224.

MELIŠ, Emanuel. O působení jednoty hudebních umělců Pražských k podporování vdov a sirotků. Dalibor, 1863, roč. 6 , č. 11, s. 81.

NORTH, Nigel. Continuo Playing on the Lute, Archlute and Theorbo. Bloomington: Indiana University Press, 1987, s. 21.

NOVOTNÝ, Václav Juda. O přednášce recitativů v J. S. Bachových oratoriích. Dalibor, 1879, roč. 1 , č. 2, s. 10.

PEČMAN, Rudolf. Händel-Konferenz 1997. Georg Friedrich Händels Oratorien und ihre Wirkung auf das kompositorische Schaffen im 19. Jahrhundert. Halle a. d. Saale, 9.-10. 6. 1997. Hudebni věda, 1997, roč. 34 , č. 4 , s. 437.

Politik, roč. 2, č. 179, 1. 7. 1863, večerní vydání, s. 1 .

Slavoj, 1864, sv. 4, č. 7, s. 115.

Slavoj, 1863, sv. 3, č. 1, s. 13-14.

Slavoj, 1865, sv. 6, č. 7, s. 113 .

Slavoj, 1865, sv. 6, č. 8, s. 130 .

SRB DEBRNOV, Josef. $Z$ deniku Bedřicha Smetany. Praha: M. Urbánek, 1902, s. 63.

ŠÍDLO, Mates. Provozování skladeb duchovních. Slavoj, 1865, roč. 6, č. 10, s. 179.

ŠMÍDOVÁ TURCHICHOVÁ, Magdalena. Znovuoživování staré hudby v českých zemích v 19. století. Muzikologické fórum, 2014, roč. 3, č. 1-2, s. 41-69.

ŠTĚDROŇ, Bohumír. Follberger, Jan. In ČERNUŠÁK, Gracian, ŠTĚDROŇ, Bohumír, NOVÁČEK, Zdenko. ČSHS I. Praha: Státní hudební vydavatelství 1963, s. 338-339.

TOMÁŠEK, Václav Jan: Vlastní životopis (ed. Zdeněk Němec). Praha: Topičova edice, 1941, s. 56-57. 
VETTERL, Karel. Bohumír Rieger a jeho doba. Časopis Matice moravské, 1929, roč. 53, s. 45-86, 435-500.

VOJTĚŠKOVÁ, Jana. Dílo Jana Dismase Zelenky v 18. a 19. století v Praze. In KROUPA, Jiří (ed.). Clavibus unitis, Praha: Nadace pro dějiny kultury ve stř̌ední Evropě, 2015, roč. 4, s. 88-89.

WOLFF, Christoph. Bach, Johann Ernst. In Grove Music Online [online]. Oxford Music Online [cit. 31. 8. 2017]. Dostupné z: http://www.oxfordmusiconline.com/subscriber/article/grove/ music/40023pg1?q=Johann+Ernst+Bachh+\%281683\%E2\%80\%931730\%29\&search=quick\&pos=1\&_start=1\#firsthit. 